\title{
Fruit Set and Berry Size of 'Fry' Muscadine Grape in Response to Six Pollen Sources
}

\author{
D. Scott NeSmith ${ }^{1}$ \\ Department of Horticulture, The University of Georgia, Georgia Station, \\ Griffin, GA 30223-1797
}

Additional index words. Vitis rotundifolia, pistillate cultivar, pollination

Muscadine grapes (Vitis rotundifolia Michx.) are grown in both large commercial vineyards and backyard settings throughout the southeastern United States. A number of muscadine cultivars are available (Himelrick and Dozier, 1993; Krewer et al., 1994), but many desirable ones for fresh fruit have only pistillate flowers. 'Fry' is a pistillate cultivar that is considered a standard throughout the Southeast (Krewer et al., 1994). Muscadine fruit set is generally low, and commercial growers require a good pollinizer for their more desirable pistillate cultivars, such as 'Fry'.

Iyer and Randhawa (1965) reported that fruit set and berry size of bunch grapes (Vitis sp.) were influenced to a degree by pollen source, but the greatest differences were between selfing and cross-pollination. Research with other small fruit crops, such as blueberry (Vaccinium sp.), has indicated that fruiting can be influenced by pollen source (Huang et al., 1997; Lyrene, 1989). However, little published information is available on the effects of pollen source on fruit set and fruit weight of muscadine grapes. This research was conducted to examine the possible influence of pollen source on fruit set, fruit weight, and fruit development period of 'Fry' muscadine grape.

A single 7-year-old 'Fry' vine was selected at the Georgia Experiment Station vineyard in

\footnotetext{
Received for publication 3 Aug. 1998. Accepted for publication 4 Nov. 1998. A contribution of The Univ. of Georgia Agricultural Experiment Station, Georgia Station, Griffin. This research was supported by state and Hatch Act funds allocated to the Georgia Agricultural Experiment Stations. The cost of publishing this paper was defrayed in part by the payment of page charges. Under postal regulations, this paper therefore must be hereby marked advertisement solely to indicate this fact.

${ }^{1}$ Associate Professor.
}

Griffin. Inflorescences having 12 or more flowers were bagged 10 to $14 \mathrm{~d}$ prior to flower opening. Inflorescences of cultivars selected for pollen sources were also bagged. In both cases, an excess number were bagged to ensure that good-quality clusters were available for pollination. Six cultivars were used as pollen sources ('Carlos', 'Cowart', 'Magnolia', 'Nesbitt', 'Southland', and 'Triumph'), and 'Fry' was also open-pollinated as a control. Six flower clusters were used for each cross. The bagged flowers were monitored two to three times weekly, and pollen was applied to 'Fry' flowers when both cultivars ('Fry' and selected pollinizer) had $>50 \%$ open blooms. The flower cluster from the pollen source was detached, and the shedding pollen was brushed all around the selected 'Fry' flower cluster. The detached flower cluster was then placed in the bag with the 'Fry' flower cluster and shaken further. The bags were removed 4 weeks after pollination. The open-pollinated control clusters were tagged for identification, but were not bagged.

The number of flowers in each 'Fry' cluster was recorded at pollination, as well as the date of pollination. All pollinations were made between 20 June and 8 July 1997 . The clusters were tagged at pollination and were harvested

Table 1. Fruit set and berry weight of 'Fry' muscadine grape in response to several pollen sources.

\begin{tabular}{lcc}
\hline \hline $\begin{array}{l}\text { Pollen } \\
\text { cultivar }\end{array}$ & $\begin{array}{c}\text { Fruit set } \\
(\%)\end{array}$ & $\begin{array}{c}\text { Berry wt } \\
(\mathrm{g})\end{array}$ \\
\hline Carlos & $20.7 \mathrm{ab}^{2}$ & $8.4 \mathrm{ab}$ \\
Nesbitt & $11.7 \mathrm{ab}$ & $10.1 \mathrm{ab}$ \\
Triumph & $15.8 \mathrm{ab}$ & $7.5 \mathrm{~b}$ \\
Cowart & $23.4 \mathrm{ab}$ & $10.6 \mathrm{a}$ \\
Magnolia & $9.4 \mathrm{ab}$ & $10.3 \mathrm{a}$ \\
Southland & $6.2 \mathrm{~b}$ & $9.7 \mathrm{ab}$ \\
Open-pollinated & $29.0 \mathrm{a}$ & $10.5 \mathrm{a}$ \\
\hline${ }^{2}$ Mean separation within & columns by LSD $_{0.05}$. Six
\end{tabular}

inflorescences were used per treatment. individually as they ripened (at least $50 \%$ of the berries matured as determined by color). The number of fruit per cluster was recorded at maturity. Individual berry weight was determined, and fruit development period was calculated from date of pollination to date of harvest. All data were subjected to analysis of variance procedures (SAS Institute, 1990).

Fruit set was not significantly affected by pollen source with but one exception, 'Southland' pollen being less effective than open-pollination (Table 1). However, variability was high, and all other pollen sources were intermediate in effect; response to 'Magnolia' was similar to that to 'Southland'. Only berries resulting from pollination with 'Triumph' pollen were significantly smaller than the open-pollinated controls, although several other treatments produced berries intermediate in size. One would expect a negative relationship between fruit set and berry weight, but none was apparent. The fruit development period ranged from $72 \mathrm{~d}$ ('Southland') to $82 \mathrm{~d}$ ('Carlos'), but was not significantly affected by pollen source (data not shown).

Although significant differences were obtained in fruit set and size in response to pollen source, this experiment should be considered preliminary pending further research. These results suggest that 'Cowart' is a good pollen source for 'Fry' when fruit set, fruit weight, and fruit development period are all considered. Currently, this planting combination is common in Georgia, and the data support its continued use. The data also suggest that 'Southland' is a poor choice. The best pollinizer for a pistillate muscadine cultivar such as 'Fry' would be one that is highly compatible and has a high degree of marketability.

\section{Literature Cited}

Himelrick, D.G. and W.A. Dozier, Jr. 1993. Commercial muscadine and bunch grape production guide. Circ. ANR-774. Alabama Coop. Ext. Serv., Auburn Univ., Ala.

Huang, Y.H., C.E. Johnson, G.A. Lang, and M.D. Sundberg. 1997. Pollen sources influence early fruit growth of southern highbush blueberry. J. Amer. Soc. Hort. Sci. 122:625-629.

Iyer, C.P.A. and G.S. Randhawa. 1965. Hybridization studies in grape. Investigations on the direct influence of pollen on some fruit and seed characters. Indian J. Hort. 22:107-121.

Krewer, G., S.C. Myers, M.E. Ferree, R. Lane, D. Horton, P. Betrand, and G. Westberry. 1994. Commercial muscadine culture. Bul. 739. Univ. of Georgia Coop. Ext. Serv., Athens.

Lyrene, P.M. 1989. Pollen source influences fruiting of 'Sharpblue' blueberry. J. Amer. Soc. Hort. Sci. 114:995-999.

SAS Institute. 1990. SAS user's guide: Statistics (6th ed.). SAS Inst., Cary, N.C. 